\title{
The Court of the Astana International Financial Center in the Wake of Its Predecessors
}

\author{
Nicolas Zambrana-Tevar*
}

\begin{abstract}
The Court of the Astana International Financial Center is a new dispute resolution initiative meant to attract investors in much the same way as it has been done in the case of the courts and arbitration mechanisms of similar financial centers in the Persian Gulf. This paper examines such initiatives from a comparative perspective, focusing on their Private International Law aspects such as jurisdiction, applicable law and recognition and enforcement of judgments and arbitration awards. The paper concludes that their success, especially in the case of the younger courts, will depend on the ability to build harmonious relationships with the domestic courts of each host country.
\end{abstract}

Keywords: international financial centers, offshore courts, international business courts, Kazakhstan

\section{Introduction}

In May 2015, the former President of Kazakhstan, Nursultan Nazarbayev, announced the creation of the Astana International Financial Centre (AIFC), which was officially launched in July 2018. The AIFC is an area within the city of Astana where a 'special legal regime in the financial sphere' applies. ${ }^{1}$ The AIFC could be classified as an offshore financial centre (OFC). Although the International Monetary Fund (IMF) has admitted that '[i]t has proven difficult to define an OFC using a widely-accepted description', ${ }^{2}$ it also refers to them as 'any

Nicolás Zambrana-Tévar LLM (LSE), PhD (Navarra), KIMEP University, n.zambrana@kimep.kz.

1. Art. 1, Constitutional Statute of the Republic of Kazakhstan on the Astana International Financial Centre, n. 438-V ZRK, 7 December 2005 (amended in 2017) (AIFC Constitutional Statute). The founding legal instruments of these financial centres are originally drafted in Arabic, Kazakh or Russian, and an unofficial translation into English is then provided by the financial centres themselves. Here, only references to the English translations are made. Laws and regulations made by the legislative and regulatory bodies of each financial centre, as well as their case law, are only in English or in English and Arabic. They can be found in the specific database of each centre's website, indicated below.

2. Offshore Financial Centers, 'A Report on the Assessment Program and Proposal for Integration with the Financial Sector Assessment Program, Monetary and Capital Markets Department and the Legal Department of the International Monetary Fund', 8 May 2008, at 17, available at: https://www.imf.org/en/Publications/Policy-Papers/Issues/ financial center where offshore activity takes place. ${ }^{3}$ 'Offshore finance is, at its simplest, the provision of financial services by banks and other agents to non-residents. ${ }^{4}$ The AIFC could also be classified as a financial free zone, ${ }^{5}$ that is an entity with only a very small or nominal territory and whose goal is mainly the provision of offshore corporate and financial services.

As part of the AIFC, the AIFC Court ${ }^{6}$ and the International Arbitration Center of the AIFC (IAC $)$ have also been created. Nine English judges have been hired, the president being the renowned Lord Woolf, former Lord Chief Justice of England and Wales, who also has extensive experience in similar dispute resolution projects, such as the Court of the Qatar Financial Center.

The AIFC is also one of Nazarbayev's ' 100 steps' ${ }^{8}$ and part of his '2050 Strategy" for the strengthening of Kazakhstan's legal system and the diversification of its economy, which is heavily dependent on its wealth of natural resources. The OECD or the American Chamber of Commerce have consistently called for solutions to the climate of corruption and disrespect for the rule of law in the country, although they also see that progress is being made. ${ }^{10}$ Anti-bribery campaigns, projects to create special investment courts, to provide better

2016/12/31/Offshore-Financial-Centers-Report-on-the-AssessmentProgram-and-Proposal-for-Integration-PP4271.

3. International Monetary Fund, 'Offshore Financial Centers, IMF Background Paper', Monetary and Exchange Affairs Department, 23 June, 2000, Section II.A, available at: https://www.imf.org/external/np/mae/ oshore/2000/eng/back.htm.

4. Ibid.

5. Infra, nn. 20-22.

6. Available at: https://aifc-court.kz/legislation. So far, only one case has been filed before the Court of the AIFC, which will be heard by the AIFC Small Claims Tribunal.

7. Available at: https://aifc-iac.kz/.

8. Address by the President of the Republic of Kazakhstan, National Plan '100 Concrete Steps to Implement the Five Institutional Reforms', 11 November 2014, available at: https://strategy2050.kz/en/page/ message_text2014/.

9. Address by the President of the Republic of Kazakhstan, 'Strategy Kazakhstan-2050: New Political Course of the Established State', 14 December 2012, available at: https://strategy2050.kz/en/ multilanguage/.

10. OECD Investment Policy Reviews: Kazakhstan 2017, at 16, available at: https://read.oecd-ilibrary.org/finance-and-investment/oecdinvestment-policy-reviews-kazakhstan-2017_9789264269606en\#page17; American Chamber of Commerce White Paper, 2018, at 2, available at: https://drive.google.com/file/d/1zlxJi9rDF7sCybKz1J8 jZR2dEdfo7EsZ/view. 
training for judges and law enforcers, ${ }^{11}$ a new but still imperfect Arbitration Law ${ }^{12}$ and now the AIFC may all be part of this effort.

The ' 100 Steps' expressly mention that the AIFC is to be modelled on the Dubai International Financial Center (DIFC, established in the United Arab Emirates (UAE) in $2004^{13}$ ), whose own dispute resolution system has served as the model for the AIFC Court and the IAC. The DIFC has also influenced the creation of similar OFCs such as the Qatar Financial Center (QFC, established in Qatar in 2005 ${ }^{14}$ ) and the Abu Dhabi Global Market (ADGM, established in UAE in 2013 ${ }^{15}$ ). A comparison between the AIFC dispute resolution mechanisms and those of its Persian Gulf predecessors may highlight the AIFC's advantages and deficiencies and may also help to predict its future success or failure. Concerning terminology, AIFC and DIFC courts are 'offshore courts' because they are established in an 'offshore jurisdiction' such as the AIFC or the DIFC and also because the use of such terminology helps to distinguish them from 'onshore courts', that is, the domestic courts of their host country, namely Kazakhstan and the UAE, respectively. ${ }^{16}$ However, the term 'offshore courts' is also often used simply to refer to the domestic courts of places like Bermuda or the British Virgin Islands, because those jurisdictions are OFCs in their own right. ${ }^{17}$

\section{Normative and Administrative Framework}

The legal system of the AIFC, as well as that of the other centres, consists of laws and regulations produced by the legislative and regulatory authorities of the host country as well as of laws and regulations made by the legislative and regulatory bodies of the centres themselves. ${ }^{18}$

First, state domestic legislation creates the financial centres and describes their basic goals, structure and man-

11. 100 Steps, Section II: 'Ensuring the rule of law', available at: https:// strategy2050.kz/en/page/message_text2014/.

12. Law of the Republic of Kazakhstan No 488-V, 8 April 2016 on arbitration, available at: http://adilet.zan.kz/eng/docs/Z1600000488.

13. 100 Steps (Step 24); DIFC, available at: https://www.difc.ae/; DIFC Courts, available at: https://www.difccourts.ae/about-courts/legalframework/.

14. QFC, available at: www.qfc.qa/en/Operate/Legal/Pages/default.aspx and Qatar International Court and Dispute Resolution Center, available at: www.qicdrc.com.qa.

15. ADGM, available at: www.adgm.com; ADGM Courts, available at: https://www.adgm.com/doing-business/adgm-courts/adgm-legalframework/adgm-courts-legal-framework/.

16. DIFC, 'Enforcement Guide', 2018, para. 71, available at: https:// issuu.com/difccourts/docs/enforcement_guide_combined_single_? $\mathrm{e}=29076707 / 61750336$

17. C. Luthi et. al., 'Bermuda: Offshore Case Digest: Issue No. 10 - Bermuda, The British Virgin Islands and The Cayman Islands', 6 March 2016, available at: www.mondaq.com. See alsowww.offshorealert.com, with case law from 'offshore' jurisdictions.

18. Supra nn. 1, 5, 6, and 12-15. agement. Reference has already been made to the Constitutional Statute establishing the AIFC. ${ }^{19}$ In the case of the DIFC and ADGM, several federal norms first opened the possibility to set up financial free zones in each of the emirates ${ }^{20}$ and then specific legislation - federal and of each emirate - created two financial centres, one in Dubai ${ }^{21}$ and then one in Abu Dhabi. ${ }^{22}$ In Qatar a law created the QFC in 2005. ${ }^{23}$

The founding legislation commonly provides for the existence of several bodies such as boards of directors, management councils and financial authorities, as well as the courts and the arbitration centres, which are autonomous and where the Chief Justice and the head of the arbitration centre play a pre-eminent role. There are also registrars with case management functions. In some centres there are judges specifically appointed for the enforcement of judgments and court orders. ${ }^{24}$

There is also a Small Claims Court or Division for disputes under a certain amount: US\$100.000 in the case of the DIFC and ADGM and US\$150.000 in the case of the AIFC. In the case of the DIFC, all dispute resolution services are under the umbrella of the DIFC Dispute Resolution Authority, which comprises the DIFC Courts, the DIFC-LCIA Arbitration Center, the DIFC Academy of Law and the Will \& Probate Registry. ${ }^{25}$

In the case of the QFC there is also a Regulatory Tribunal that decides appeals against decisions made by QFC administrative bodies. ${ }^{26}$ In the other centres, jurisdiction for these kinds of 'internal' administrative law disputes is conferred on the offshore courts themselves, along with their general jurisdiction for civil and commercial claims. In all cases there is a first instance court or circuit and a court of appeal, with the additional possibility of creating different divisions within the courts (e.g. an employment division in the ADGM Courts ${ }^{27}$ ).

ADGM Courts are modelled on Scotland's Court of Sessions, so that ADGM judges can sit in both the Court of First Instance and in the Court of Appeal, as

19. Supra n. 1. For the nature of constitutional statutes, see Art. 62.4 of the Constitution of the Republic of Kazakhstan, 1995, available at: www.akorda.kz/en/official_documents/constitution and Art. 1.12 of the Law of the Republic of Kazakhstan, 6 April 2016 NO 480-V LRK 'On legal acts', available at: http://adilet.zan.kz/eng/docs/ Z1600000480.

20. Art. 121 UAE Constitution of 1971 (permanently adopted in 1996), as amended by Constitutional Amendment 1 of 2004, available at: https://www.constituteproject.org/constitution/

United_Arab_Emirates_2004.pdf; UAE Federal Law 8 of 2004 Regarding Financial Free Zones.

21. UAE Federal Decree 35 of 2004, to establish a Financial Free Zone in Dubai; Dubai Law No. 9 of 2004 in respect of the Dubai International Financial Center (DIFC Law).

22. UAE Federal Decree No. 15 of 2013 concerning the establishment of a financial free zone in the Emirate of Abu Dhabi; Abu Dhabi Law No. 4 of 2013 Concerning the Abu Dhabi Global Market (ADGM Law).

23. Qatar Financial Center Law 7 of 2005 (amended by Law No. 2 of 2009 and Law No 14 of 2009) (QFC Law).

24. Infra, nn. 90, 109, and 122.

25. Art. 8 DIFC Law.

26. Art. 8.2 QFC Law.

27. Rule 3, ADGM Divisions and Jurisdiction (Court of First Instance) Rules of 2015 (ADGM Court Rules). 
required, with the prohibition that they may not sit on appeal from their own first instance judgment. ${ }^{28}$

AIFC Courts are not a part of the judicial system of Kazakhstan. ${ }^{29}$ However, the Constitution of Kazakhstan does not seem to allow for any 'parallel' judicial system where it indicates that 'The judicial system of the Republic shall be established by the Constitution of the Republic and the constitutional law. The establishment of special and extraordinary courts under any name shall not be allowed' ${ }^{30} \mathrm{~A}$ recent amendment to the constitution allows for a special financial regime in the AIFC but does not mention the AIFC Court as such. ${ }^{31}$ Similarly, the creation of the DIFC and ADGM also needed a reform of the UAE Federal Constitution. ${ }^{32}$ Some Kazakhstani academics question the constitutionality of the AIFC legal regime. ${ }^{33}$ However, given the dubious separation of powers in Kazakhstan and the amount of resources and prestige invested by its government, there may be little risk that a 'moot technicality' will affect the functioning of the AIFC, at least for the time being.

\section{Subject-Matter Jurisdiction}

All of the courts examined here have jurisdiction in 'civil and commercial' matters. ${ }^{34}$ Concerning the AIFC, its Constitutional Statute may shed some light on this expression by clarifying that AIFC bodies have legislative jurisdiction for the following kinds of relationships among the different types of AIFC bodies, participants and their employees: civil relationships; civil procedural relationships; financial relationships; administrative procedures. ${ }^{35}$ However, as in the case of the ADGM, family disputes seem to be excluded. ${ }^{36}$

The four courts also have jurisdiction in employment disputes between employees and the centres' business establishments they work for. ${ }^{37}$ Prior to an amendment of Article 5 of the DIFC Judicial Authority Law, introduced by Dubai Law No. 5 of 2017, it was unclear

28. B. Reynolds, 'The Abu Dhabi Global Market: Legislative Framework, Approach and Methodology', 32(5) J.I.B.L.R. 197 (2017)

29. Art. 13 AIFC Constitutional Statute; Art. 3.5 and Art. 4 Constitutional Law of the Republic of Kazakhstan, 25 December 2000, N. 132, 'On the Judicial System and Status of Judges in the Republic of Kazakhstan', available at: http://adilet.zan.kz/eng/docs/Z000000132

30. Art. 75.4 Constitution of the Republic of Kazakhstan of 1995.

31. New Art. 2.3.1 introduced by the Constitutional law of the Republic of Kazakhstan N. 51-VI 3RK, 10 March 2017, available at: https:// online.zakon.kz/Document/?doc_id=34929984\#pos=1;-26.

32. Supra n. 20.

33. A. Shaikenov and V. Shaikenov, 'Is the AIFC constitutional and will amendments to the Constitution legitimize it?', Forbes Kazakhstan, 7 March 2017; interview of the author with Prof. Z. Kembayev, KIMEP University.

34. Art. 5.A, Dubai Law 16 of 2011 amending Law 12 of 2004 (DIFC Judicial Authority Law); Art. 8.3 QFC Law; Art. 26.2 AIFC Court Regulations.

35. Art. 4.3.

36. Rule 2.2.b ADGM Court Rules.

37. Art. 26.1.a) AIFC Court Regulations; Rule 3, ADGM Court Rules; Art. 9.1 .3 QFC Court Rules. whether the DIFC Courts had jurisdiction in employment disputes. ${ }^{38}$

Jurisdiction in criminal matters is also excluded from all the courts. ${ }^{39}$ This exclusion may significantly reduce the usefulness of the AIFC Court because it is in the context of tax and administrative law-related criminal proceedings in Kazakhstan that many investors' complaints materialise. It is not unheard of that relatively minor accounting differences are treated as serious accusations of accounting fraud where employees of foreign companies risk going to jail. It is not atypical, either, that violations of subsoil use or of environmental regulations are used as a means to put pressure on investors, in contract renegotiations with the government. ${ }^{40}$ Nevertheless, the AIFC Court and the other three courts have the jurisdiction to interpret the laws enacted within each centre and to rule on the scope of their jurisdiction. ${ }^{41}$ The only case found regarding jurisdiction in cases of a mixed nature - from the ADGM Courts - abstains from giving a solution. ${ }^{42}$

\section{General Jurisdiction over AIFC 'Centre Participants'}

The jurisdiction of the AIFC Court depends on whether the parties are established within or licensed by the financial centre and on whether the dispute arises out of activities carried out within the AIFC and regulated by AIFC law. The jurisdiction of the other offshore courts - especially the DIFC - is broader and focuses on whether contracts are performed within each financial centre and on whether there is at least one party to the dispute established within the centre. Additionally, the courts may also have jurisdiction under choice of court agreements. The laws and regulations of the centres also commonly include final catch-all provisions granting jurisdiction if any other future law or regulation of each centre so indicates.

AIFC rules grant 'exclusive jurisdiction' where all the parties to the dispute are either AIFC Participants, a managing body of the center and/or foreign employees, ${ }^{43}$ regardless of where the contract is made; where

38. H. I. Alustath, 'Choice of Law in respect of contracts in the United Arab Emirates and the European Union; and Related Aspects of Private International Law in Relation to the Dubai International Financial Center', (PhD Dissertation at University of Essex, 2015:153).

39. Art. 8 Second 6, DIFC Law; Art. 5 ADGM Courts, Civil Evidence, Judgments, Enforcement and Judicial Appointments Regulations 2015 (ADGM Court Regulations); Art. 13.4 AIFC Constitutional Statute.

40. Personal interviews of the author with several local lawyers and business consultants.

41. Art. 8 Second, 7 DIFC Law; Art. 9.4 QFC Court Regulations and Procedural Rules of 2010 (QFC Court Rules); Art. 13.10 AIFC Constitutional Statute and Art. 26. 2 AIFC Court Regulations.

42. Karim Berardo v. Stumpf Energy Ltd, ADGM Court of First Instance, Employment Division, [2018] ADGMCFI 1, para. 6, available at: https:// www.adgm.com/doing-business/adgm-courts/judgments/court-offirst-instance/.

43. Art. 13.1 AIFC Constitutional Statute; Art. 26.1.a) AIFC Court Regulations. 
the place of performance of the contractual obligation is, within or without the AIFC; and also regardless of whether such dispute deals with the kind of services and activities for which the center was founded. In the absence of a submission agreement, disputes between an AIFC Participant and a non-AIFC Participant seem to be excluded unless they fall within one of the other heads of jurisdiction, as explained below.

The AIFC Court Regulations only mention 'foreign employees'44 under this head of general jurisdiction, so that disputes involving employees who are nationals of Kazakhstan seem to fall solely within the jurisdiction of the onshore courts.

The grant of 'exclusive jurisdiction' - terminology also used by the DIFC rules - may reinforce the idea that the domestic courts of Kazakhstan cannot intervene in disputes where all parties are AIFC Center Participants and also in cases where the dispute relates to operations carried out within the AIFC and that are regulated by the law of the AIFC or, finally, where the parties have chosen the AIFC Courts.

For the purposes of jurisdiction, who the Center Participants are may be a little confusing because the English translation of the AIFC Constitutional Statute, - originally drafted in Russian - defines them as "legal entities registered under the Acting Law of the AIFC and legal entities recognized by the AIFC" whereas the AIFC Glossary, ${ }^{45}$ - drafted in English -, defines them as "legal entities incorporated pursuant to the Acting law of the Center, and other legal entities accredited by the Center".

A reading of the remaining normative instruments may help to understand that Center Participants are legal entities incorporated under the law of the AIFC, as well as branches and representative offices of entities incorporated in Kazakhstan or abroad but that have received a commercial licence or 'order' to operate within the AIFC, such as authorised firms, authorised market institutions, ancillary service providers or recognised non-AIFC members. ${ }^{46}$

\section{Specific Jurisdiction for Disputes Arising out of Operations Within the Centres}

AIFC rules grant exclusive jurisdiction to AIFC Courts in disputes relating to 'operations carried out in the AIFC and regulated by the law' of the centre. ${ }^{47}$ Regarding which type of 'operations' can be carried out within the AIFC and, therefore, be the subject matter of these

\footnotetext{
44. Art. 26 AIFC Court Regulations.

45. AIFC Glossary, AIFC Act No. FR0017 of 2018 (Centre Participant).

46. See AIFC Glossary for these terms.

47. Art. 13.1 AIFC Constitutional Statute; Art. 26.1.b) AIFC Court Regulations.
}

claims, the AIFC Constitutional Statute indicates that the AIFC's purpose is to develop a market with respect to securities, insurance, banking, Islamic finance, financial technologies, electronic commerce and innovative projects', as well as financial and professional services. ${ }^{48}$ Activities such as real estate and precious metals are also mentioned in the AIFC Glossary. ${ }^{49}$ Significantly, given the important extracting industry of Kazakhstan, activities related to the oil and extracting industries are not mentioned.

For the purpose of clarifying their scope of application, the Financial Services Framework Regulations indicate that '[a] Person will be deemed to be carrying on activities in the AIFC' if 'that Person is a Center Participant and the day-to-day management of those activities (even if those activities are undertaken in whole or in part from outside the AIFC) is the responsibility of the Center Participant in its capacity as such; or that Person's head office is outside the AIFC but the activity is carried on from a branch maintained by it in the AIFC; or the activities are conducted in circumstances that are deemed to amount to activities carried on in the AIFC.... 50

Operations 'regulated by the law of the AIFC' probably do not mean the same as 'regulated activities' - investments, insurance, etc. - which are dealt with separately and for which a special authorisation is needed and specific regulations provided. ${ }^{51}$ 'Regulated by the law of the AIFC' may be taken to mean that the activity or operation that is the subject matter of the dispute must be governed or regulated by any laws or regulations made by the AIFC legislative or regulatory bodies, including the AIFC Constitutional Statute, although this is actually a law of Kazakhstan.

Operations 'regulated by the law of the AIFC' probably do not mean, either, that the contract itself must be governed by AIFC law, in a contractual dispute. The AIFC has its own contract law, ${ }^{52}$ but, in a financial transaction between AIFC Participants and non-AIFC Participants, the parties may well have chosen English law to govern their contract, while, at the same time, the financial operation itself may be subject to different AIFC regulations, financial or otherwise, in which case the AIFC Courts would have jurisdiction, even though they will apply English law to the rights and obligations of the parties under the contract.

Furthermore, depending on the extraterritorial reach of AIFC legislation, there may be cases where the operation may have taken place outside the AIFC, while at the same time being effectively 'regulated by the law of the AIFC'. However, the AIFC Court probably would not have jurisdiction in such cases because the operation must be carried out in the AIFC and be regulated by AIFC law.

\footnotetext{
48. Art. 2 AIFC Constitutional Statute.

49. AlFC Glossary (Designated Non-Financial Business and Profession).

50. Section 6 Financial Services Framework Regulations, AIFC Regulations No. 18 of 2017

51. AIFC General Rules, AIFC Rules No. FR0001 of 2017

52. AIFC Contract Regulations, AIFC Regulations No. 3 of 2017.
} 
The AIFC Contract Regulations themselves provide for yet another head of jurisdiction. These Regulations 'govern contracts made between AIFC Participants, AIFC Bodies and AIFC Participants, and AIFC Bodies, unless otherwise expressly provided in a contract', and '[a]ny contract governed by these Regulations is subject to the jurisdiction of the Court unless otherwise expressly provided in a contract'. 53

However, if there is at least one party to the contract who is not an AIFC Participant or AIFC Body, the Contract Regulations do not apply and, in the absence of an express choice of the AIFC Contract Regulations or a choice of the AIFC Courts, the latter would not have jurisdiction.

Therefore, a contract between two AIFC Participants may be subject to the jurisdiction of the AIFC Court, regardless of whether the 'operation' is carried out within the AIFC. Additionally, the AIFC Court may have jurisdiction where the only link to the AIFC is the parties' choice of the AIFC Contract Regulations, regardless of their being AIFC Participants, unless the parties have submitted to the jurisdiction of another court.

Regarding the conjunction 'and' in the sentence 'operations carried out in the AIFC and regulated by the law' of the AIFC, it is also possible to imagine business operations that are carried out within the AIFC but that are not necessarily regulated by AIFC law (e.g. a cafeteria located inside the AIFC) and, conversely, there may be operations that are regulated by AIFC law but where all or part of its elements may not take place within the financial centre (e.g. a securities transaction where the depositary of the securities is located in Luxemburg). Therefore, 'and' probably means that both conditions must be met and that there are not two different heads of jurisdiction.

The jurisdiction rules of the AIFC Court indicate that the reference to 'disputes' also includes 'incidences', which may grant the Court jurisdiction for tort claims, as long as the 'incidence' is also 'regulated by the law of the AIFC' ${ }^{54}$ The AIFC Regulations on Obligations regulate tort liability and are applicable in the jurisdiction of the' AIFC. This expression does not seem to be very helpful in those cases where it is difficult to determine whether all or any of the elements of the tort have taken place inside or outside of the centre.

Finally, although the AIFC jurisdiction rules clearly have in mind legal entities as parties to civil proceedings before the AIFC Court, natural persons - and not just employees in employment disputes - may also be parties in civil and commercial disputes in their capacity as corporate officials of a Participant, individual registered auditors, individual lawyers or also as individual entrepreneurs.

The jurisdiction of the DIFC Court of First Instance is broader than that of the AIFC. ${ }^{55}$ It suffices that the

53. Art. 7 AIFC Contract Regulations.

54. Art. 5, AIFC Regulations on Obligations, No. 16 of 2017

55. Art. 5.A.1, DIFC Judicial Authority Law; P. Punwar, The Rules of the DIFC Courts with Commentary \& Materials (London: Sweet \& Maxwell) (2011).
DIFC itself or any of its bodies or any Center Establishment or Center Licensed Establishment is a party to the claim. Disputes where only one of the parties is either an entity incorporated within the DIFC or a licensed branch of a business incorporated elsewhere fall under the jurisdiction of the DIFC Courts, unless the parties have opted out. However, the doctrine of forum non conveniens may operate where there are no sufficient connections between the claim and the centre. ${ }^{56}$

The jurisdiction of the DIFC Court also encompasses claims 'arising from or related to' contracts made, concluded, carried out or supposed to be carried out, in whole or in part, within the DIFC, in accordance with the explicit or implicit terms of the contract and regardless of whether any of the parties to the contract is established within the DIFC. ${ }^{57}$ This provision does not add - as the AIFC rules do - that such contracts must be regulated by the law of the DIFC.

DIFC Courts will also have jurisdiction for claims 'arising out of or relating to any incident or transaction which has been wholly or partly performed within [the] DIFC and is related to DIFC activities'. ${ }^{58}$ For instance, the DIFC Courts would have jurisdictions for disputes arising out of torts or donations, provided that the place of the causal event or the place where the donation is made is within the DIFC and the tort or the donation is somehow related to the financial or ancillary activities for which the centre was founded.

QFC Courts have jurisdiction for any kind of civil and commercial disputes between business entities established within the QFC, regardless of the place of performance of the contractual obligation; between QFC management bodies and businesses established within the QFC; and between entities established within the centre and individual residents of Qatar or entities established in Qatar but outside the QFC, unless there is an express submission to other courts. ${ }^{59}$

QFC Courts also have jurisdiction for civil and commercial disputes between business entities established within the QFC 'and contractors therewith', that is, any individual or legal entity with which an entity established in the QFC enters into a contract and that does not fall into any of the categories in the other paragraphs.

56. Corinth Pipeworks SA v. Barclays Bank Plc, [2011] DIFC CA 002, para. 66, available at: https://www.difccourts.ae/2011/01/22/ca-0022011corinth-pipeworks-sa-v-barclays-bank-plc/; Mr Rafed Abdel Mohsen Bader Al Khorafi (2) Mrs Amrah Ali Abdel Latif Al Hamad (3) Mrs Alia Mohamed Sulaiman Al Rifai v. (1) Bank Sarasin-Alpen (ME) Limited (2) Bank Sarasin \& Co. Ltd, [2011] DIFC CA 003, para. 109, available at: https://www.difccourts.ae/2012/01/05/ca-0032011-1-mr-rafedabdel-mohsen-bader-al-khorafi-2-mrs-amrah-ali-abdel-latif-alhamad-3-mrs-alia-mohamed-sulaiman-al-rifai-v-1-bank-sarasin-alpenlimited-2-bank-sarasin-co-Itd/.

57. Art. 5.A.1.b; CFI 018/2016 Standard Chartered Bank v. (1) Fal Oil Company Limited (2) Investment Group Private Limited, para. 10, available at: https://www.difccourts.ae/2018/08/30/cfi-018-2016standard-chartered-bank-vs-1-fal-oil-company-limited-2-investmentgroup-private-limited/.

58. Art. 5.A.1.c. DIFC Judicial Authority Law.

59. Art. 8.3 QFC Law; Art. 9.1 QFC Court Rules; McNair Chambers, 'The QFC Civil and Commercial Court: The Essentials', 2010, at 7, available at: https://www.mcnairchambers.com/client/publications/2010/ McNair_QFC_Court_Guide_Second_Edition_September_2010.pdf. 
Therefore, as in the case of the DIFC, the QFC Court will have jurisdiction to hear claims where only one of the parties is established within the centre, without regard to whether the contract deals with the activities of the QFC..$^{60}$

Finally, QFC Courts also have jurisdiction for disputes between business entities established within the QFC 'and employees thereof', that is, employment disputes between QFC establishments and the expats working for them. However, if an employee files an employment claim before the QFC's Employment Standard's Office, he cannot appeal the Office's decision before the QFC Court. ${ }^{61}$

The Court of First Instance of the ADGM has jurisdiction in 'civil and commercial disputes arising out of or relating to a contract or a transaction conducted in whole or in part in the Global Market or to an incident that occurred in the Global Market', ${ }^{62}$ unless they opt out of the jurisdiction. Therefore, the place where the parties to the dispute are established does not seem to play a role.

\section{Express Submission}

Choice of court agreements are also a common basis of jurisdiction, regardless of whether the parties to the agreement are centre participants or are licensed to operate in each of the centres. ${ }^{63}$ This may indeed prove useful for those foreign investors that are already established in the host country and/or have business dealings with local entities owned or related to the host government, because such entities may be willing or allowed to submit to the jurisdiction of these 'local' offshore courts, but not to the jurisdiction of foreign courts or arbitration tribunals, without due authorisation. ${ }^{64}$

Although the AIFC Court Regulations grant jurisdiction for 'disputes transferred [...] by agreement of the parties', they add that ' $[t]$ he Court shall consider the express accord of the parties to a case that the Court shall have jurisdiction and if the Court considers it desirable or appropriate, it may decline jurisdiction or may refer any proceedings to another Court within the Republic of Kazakhstan'. This seems to grant discretion to the AIFC Court in deciding whether to take jurisdiction if the case is not sufficiently connected with the AIFC. Even more ambiguously, the QFC rules indicate that 'the Court will take into account the expressed accord of the parties that the Court shall have jurisdiction'. ${ }^{65}$

DIFC and ADGM rules expressly establish that the submission agreement must be in writing, but nothing is stated about the written form in the case of the AIFC. The DIFC Courts Registry accepts claim forms filed by the parties if accompanied by choice of court agreements with the specific wording provided by a practice direction, subject to the right of the DIFC Courts to rule on their own jurisdiction once the proceedings have commenced. ${ }^{66}$

Finally, the defendant's acknowledgment of service does not make him forfeit his right to dispute the DIFC Court's jurisdiction, provided that the application to dispute the Court's jurisdiction is made within a specified period. ${ }^{67}$

\section{Applicable Law}

One of the issues that have raised more interest is the supposed application of English law within these four financial centres. The DIFC has been referred to as a 'common law oasis in a civil law ocean'. ${ }^{68}$ 'Part-time' judges from common law jurisdictions have been hired, as in some English-speaking countries of the Caribbean, the style of litigation is clearly adversarial and some traditional common law litigation weapons such as quashing orders, freezing orders or search orders have also been adopted. However, the extent to which English law is actually applied varies significantly from centre to centre.

The provisions concerning the scope of AIFC law and the law to be applied by the AIFC Court are confusing. The procedural law is, basically, the AIFC Court Regulations and AIFC Court Rules, which closely follow the English Civil Procedure Rules. ${ }^{69}$ Concerning both the procedural and the substantive law to be applied, '[t]he activities of the AIFC Court are governed by the resolution of the Council On the Court of Astana International
60. QFC Case 09/2010, Nazim Omara v. Al Mal Bank LLC (in liquidation), para. 8, available at: https://www.qicdrc.com.qa/sites/default/files/s3/ judgments/english/09.2010\%2012\%20Dec\%202010.pdf.

61. QFC Case 01/2018, Abdulla Jasim Al Tamimi v. QFC Financial Authority and Qatar Finance and Business Academy LLC, paras. 16-18, available at: https://www.qicdrc.com.qa/sites/default/files/s3/judgments/ english/case_no_1_of_2018_judgment_13_may_2018.pdf.

62. Art. 13.6 ADGM Law; H. Quinlan, et al., 'Abu Dhabi Global Market courts: framework, procedures and first judgment summary', Practical Law Global Guide, 2018, available at: https:// uk.practicallaw.thomsonreuters.com/w-013-7809?

transitionType $=$ Default $\&$ contextData $=($ sc. Default $) \&$ firstPage $=$ true $\&$ com $\mathrm{p}=$ pluk\&bhcp $=1$.

63. Art. 26.1.C and 26.3 AIFC Court Regulations; Art. 5.A.2 DIFC Judicial Authority Law; Art. 16.2e) ADGM Court Regulations; Art. 9.2 QFC Court Rules.

64. Art. 8.10 Arbitration law of Kazakhstan; supra n. 12.
65. Art 9.2 QFC Court Rules.

66. 'Practice Direction No. 2 of 2012 DIFC Courts' Jurisdiction', 2012, available at: https://www.difccourts.ae/2012/03/08/practice-directionno-2-of-2012-difc-courts-jurisdiction/; D. P., Horigan, 'Consensual Jurisdiction of the DIFC Courts', Proceedings of 20th International Business Research Conference, Dubai, April 2013, at 5 et seq

67. E.g. Part 12 of DIFC Court Rules.

68. M. Hwang, Deputy Chief Justice of the DIFC Courts, 'The Courts of the DIFC', Address at the Lawasia Conference, Kuala Lumpur, 1 November 2008, available at: https://www.difccourts.ae/2008/11/01/the-courtsof-the-dubai-international-finance-centre-a-common-law-island-in-acivil-law-ocean/.

69. P. Fisher, 'Ambitions for Astana', Practical Law Construction Blog, 7 March 2018, at 4, available at: http://constructionblog.practical law.com/ambitions-for-astana/. 
Financial Centre ${ }^{70}$ which is based on the principles and legislation of the law of England and Wales and the standards of leading global financial centres'. The AIFC Court is also 'bound by the Acting Law of the AIFC and may also take into account final judgements of the AIFC Court in related matters and final judgements of the courts of other common law jurisdictions'. ${ }^{71}$

The AIFC 'Acting Law' consists of

[the AIFC] Constitutional Statute; AIFC Acts, which are not inconsistent with this Constitutional Statute and which may be based on the principles, legislation and precedents of the law of England and Wales and the standards of leading global financial centres, adopted by the AIFC Bodies in the exercise of the powers given by this Constitutional Statute; and the Acting Law of the Republic of Kazakhstan, which applies in part to matters not governed by this Constitutional Statute and AIFC Acts. ${ }^{72}$

Thus, the law of Kazakhstan plays only a residual role, and case law may only 'guide' the decisions of the court. In line with the foregoing, the substantive law to be applied by the AIFC Court will therefore be the laws and regulations of the centre, such law as it is agreed on by the parties - unless it is contrary to the public order or public policy of Kazakhstan - or such law as it appears to the Court to be the most appropriate to the facts and circumstances of the dispute. ${ }^{73}$

The AIFC Regulation on AIFC Acts does help to clarify this issue. ${ }^{74}$ Generally, Article 40.2 seems to call for the application of AIFC law in regulatory matters; otherwise, in subsidiary order, the applicable law is the law 'agreed between all the relevant Persons concerned in the matter', the law of the place 'most closely related to the facts of and the Persons concerned in the matter', and the law of Kazakhstan.

The AIFC Regulation on AIFC Acts also indicates that '[a]n express choice of a governing law in a contract is effective against all Persons affected by the choice'. Such law governs 'the existence, validity, effect, interpretation and performance of [the] contract, or any terms of [the] contract, including any requirements as to formality'. In the absence of an express choice, 'the contract is governed by the Acting Law of the AIFC'.

The capacity and authority of agents are governed by the applicable law to the contract. The rights and liabilities of the principal in relation to third parties are governed by the applicable law to the contract between the third parties and the agent, if the latter acts on behalf of the principal. There is also a provision on the law appli-

70. This resolution does not seem to be available; available at: https:// aifc.kz/management/main.

71. Art. 13.5 and Art. 13.6 AIFC Constitutional Statute.

72. Art. 4.1 AIFC Constitutional Statute.

73. Art. 13.6 AIFC Constitutional Statute and Art. 29 AIFC Court Regulations.

74. Arts. 39 et seq. AIFC Regulations on AIFC Acts, AIFC Regulations No. 1 of 2017. cable to legal subrogation that is taken almost entirely from Article 15 of EU Regulation Rome I. ${ }^{75}$

The laws applicable in the DIFC are the centre's own laws and regulations. ${ }^{76}$ Concerning the law applicable to the merits of a dispute, the DIFC Courts will apply the domestic law expressly chosen by the parties and, in the absence of choice, the DIFC's internal legislation, especially in regulatory matters and where such legislation is of a mandatory nature. In the absence of specific DIFC laws applicable to the dispute, the laws of England and Wales - or even those of other common law jurisdictions - may be imported, including the possibility to take into consideration rulings from other jurisdictions. $^{77}$

There have been doubts about the availability of UAE domestic law as the law chosen by the parties in DIFC litigation. ${ }^{78}$ This may be because the DIFC legal system was established as a separate legal system. But if the DIFC Courts can apply foreign domestic law, there is little reason why UAE law could not be applied too, if chosen by the parties. ${ }^{79}$

The law chosen by the parties in DIFC litigation shall not be applied where it conflicts with public policy and public morals. ${ }^{80}$ This reference to public morals - in addition to public policy - turns into a reference to public order in the cases of the $\mathrm{QFC}^{81}$ and the $\mathrm{AIFC}^{82}$ and is probably an honest reminder that customs and traditions in some Muslim countries are different from those of the West. ${ }^{83}$ Despite the fact that these centres are meant to attract many foreign employees and their corresponding families, the black letter of the law does not seem to provide for any accommodations for such an additional multicultural population. An express choice of law may also be disregarded if it is contrary to DIFC overriding mandatory rules, such as those with regulatory content. ${ }^{84}$

The ADGM provides for a general application of the law of England and Wales within the centre, 'as it stands from time to time', including English rules of equity. ${ }^{85}$ Nevertheless, this daring incorporation of a whole for-

75. Ibid., Arts. 45 and 46

76. Art. 13.1 DIFC Law.

77. Art. 8, DIFC Law 3 of 2004; Arts. 7.2, 8, 9 and 10, DIFC Law 10 of 2005; Art. 30, DIFC Law 10 of 2004 (DIFC Court Law) and Art. 6 DIFC Judicial Authority Law; Alustath, above n. 38, at 136-45.

78. Rasmala Investments Limited v. Various Defendants, [2009] DIFC CFI 001-006/2009, available at: https://www.difccourts.ae/2009/04/06/ cfi-001-0062009-rasmala-investments-limited-v-various-defendants/; National Bonds Corporation PJSC v. (1) Taaleem PJSC and (2) Deyaar Development PJSC, [2011] DIFC CA 001, paras. 39 et seq., available at: https://www.difccourts.ae/2011/05/11/ca-0012011-national-bondscorporation-pjsc-v-1-taaleem-pjsc-and-2-deyaar-development-pjsc/.

79. Alustath, above n. 38, at 141.

80. Art. 6 DIFC Judicial Authority Law.

81. Art. 11.1 QFC Court Rules.

82. Art. 29 AIFC Court Regulations.

83. Art. 7 of the UAE Federal Constitution provides that Sharia law is the 'main source of legislation in the UAE'; Art. 12 DIFC Law 9 of 2004 (prohibition of 'products and goods carrying inscriptions, drawings, trademarks or signs considered to contradict religious teachings and beliefs or public morals').

84. Alustath, above n. 38, at 142-43.

85. Arts. 1 and 3 ADGM Application of English Law Regulations of 2015. 
eign legal system is subject to many qualifications. English law is meant to be applied 'so far as it is applicable to the circumstances of the' ADGM, 'subject to any modifications as those circumstances require', 'subject to any amendment thereof' made by the laws of the $\mathrm{ADGM}^{86}$ and notwithstanding any changes made to the law of England after the enactment of ADGM regulations. Such changes will be applicable in the centre only once there is an express incorporation of each new English law into the legal system of the ADGM. Any contradictions between English law and the laws and regulations of the ADGM must be resolved in favour of the latter. Nothing is expressly said about choice of law agreements. However, it may be implied that English rules on choice of law agreements - including, for as long as the $\mathrm{UK}$ is part of the $\mathrm{EU}$, any specific $\mathrm{EU}$ rules on this matter - are also applicable.

The founding law of the QFC indicates that the laws and regulations of the centre shall apply to the contracts, transactions and arrangements conducted by the entities established in, or operating from the QFC, with parties or entities located in the QFC or in Qatar but outside the QFC, unless the parties agree otherwise. ${ }^{87}$ There is also an ambiguous reference to the fact that the QFC Court 'will ordinarily determine the dispute in accordance with' the law agreed on by the parties, although such choice will be disregarded if it is inconsistent with Qatar's public order, public policy or the QFC's consumer regulations. ${ }^{88}$

Concerning the status of foreign law and the procedure to prove it in court, the DIFC Court Rules provide that the party intending to put in evidence a finding on a question of non-DIFC law must give prior notice specifying the question on which the finding was made. The notice must indicate whether there is going to be expert evidence on the issue of the foreign law and provide a copy of the document where the foreign law is reported. ${ }^{89}$ The ADGM Court Regulations provide for the possibility to give expert evidence on foreign law or, in certain cases, for filing judicial decisions where such point of law has been heard in application of foreign law. ${ }^{90}$

\section{Recognition and Enforcement of Judgments and Other Judicial Decisions}

An AIFC enforcement judge, in accordance with AIFC law, enforces judgments, orders and directions of the

Modifications have been made to English laws such as the Statute of Frauds of 1677, Law of Property Act of 1925, the Contracts (Rights of Third Parties) Act of 1999 and the Partnership Act of 1890; Reynolds, above n. 28, at 184

87. Art. 18.3 QFC Law

88. Art. 11.1.2 QFC Court Rules.

89. Rule 29.131 et seq. DIFC Court Rules.

90. Art. 73 ADGM Court Regulations.
AIFC Court within the AIFC. ${ }^{91}$ The AIFC Court 'may issue rules or practice directions for the further enforcement of other judgments and arbitration awards', ${ }^{92}$ so one should expect that new guidelines and/or agreements with domestic or foreign courts will be issued in the future, for the purpose of recognition and enforcement, as in the case of the other centres. In fact, the AIFC Court is already a member of SIFoCC (Standing International Forum of Commercial Courts), ${ }^{93}$ which may facilitate recognition and enforcement by means of memoranda of understanding (MoUs) and informal arrangements.

Enforcement of AIFC decisions in the territory of Kazakhstan is to be done 'in the same way and on the same terms' as decisions of the 'onshore' courts. ${ }^{94}$ Parties must first apply for an 'execution order' from the AIFC Court and then translate the decision into Russian or Kazakh..$^{95}$ The AIFC Court has already concluded an $\mathrm{MoU}^{96}$ with the Republican Chamber of Private Bailiffs ${ }^{97}$ in charge of enforcing rulings from domestic courts. A legal reform is said to be in progress at the Senate of Kazakhstan, which would simply include the AIFC Court among the list of courts whose decisions and orders are to be enforced by such bailiffs, in accordance with domestic legislation. ${ }^{98}$ Despite this future legal reform, there may still be difficulties in the enforcement process, especially if the AIFC Court grants remedies that are unknown in the legal system of Kazakhstan.

Decisions of the domestic courts of Kazakhstan 'are to be enforced in the AIFC in accordance with [the] legislation' of Kazakhstan. ${ }^{99}$ This provision may simply mean that Kazakhstani judgments will have the same effects within the AIFC that they have in the rest of Kazakhstan. It probably does not mean that the AIFC Court has to apply the domestic Code of Civil Procedure $^{100}$ in these cases. It may also be an announcement of future domestic legislation concerning enforcement of AIFC Court decisions, or it may even be taken as a grant of jurisdiction to the 'onshore' courts in certain matters pertaining to enforcement, parallel litigation or res judicata issues.

Little is said about the recognition and enforcement of foreign judgments within the AIFC or about recogni-

91. Arts. 17 and 40 AIFC Court Regulations; Rule 30.4 AIFC Court Rules.

92. Art. 40.3 AIFC Court Regulations.

93. Available at: https://www.sifocc.org/countries/kazakhstan/.

94. Art. 13.8 AIFC Constitutional Statute.

95. Rule 30.2 AIFC Court Rules.

96. Available at: http://old.aifc.kz/ru/news/103.html.

97. Arts. 161 et seq. Law of the Republic of Kazakhstan, 'On Enforcement Proceedings and the Status of Enforcement Agents', 2 April 2010, No. 261-IV, available at: http://adilet.zan.kz/eng/docs/Z100000261_; B. Tukulov, 'On the Court and Arbitration at the Astana International Financial Center', at 2, available at: www.gratanet.com/up_files/AIFC \%20Article\%20Eng\%2014\%20Aug\%202018.pdf.

98. Lecture given by Sir Jack Beatson, Justice of the AIFC Court at KIMEP University, Almaty, 19 April 2019.

99. Art. 13.9 AIFC Constitutional Statute.

100. Code of Civil Procedure No. 377-V, 31 October 2015 (as amended by Law of the Republic of Kazakhstan No. 489-V, 8 April 2016), available at: http://adilet.zan.kz/rus/docs/K1500000377. 
tion of AIFC Court judgments abroad, other than the possibility to obtain a certified copy of the AIFC judgment. ${ }^{101}$ With respect to enforcement abroad, it is significant that the AIFC Court is expressly excluded from the domestic judicial system of the host country because the architects of the AIFC could have done otherwise and because they have not followed the example of the DIFC in this specific point. This may mean that parties to AIFC Court proceedings cannot avail themselves of the very few treaties on recognition to which Kazakhstan is a party - mostly with Commonwealth of Independent States (CIS) countries - and that are applicable by Kazakhstani courts. ${ }^{102}$

If AIFC Court judgments cannot be characterised as judgments of a court of the Republic of Kazakhstan, not only may the aforementioned treaties not apply, but it is fair to ask whether, whenever AIFC Court judgments travel abroad, the country where recognition is sought may be able to apply its own internal provisions on recognition based on reciprocity because such provisions are commonly applicable to judgments issued by courts belonging to the judiciary of some country.

AIFC Court judgments - as opposed to IAC arbitral awards - cannot be characterised as arbitral awards, either, for the purposes of recognition under the New York Convention (NYCV), because the AIFC Courts are not arbitration tribunals. Submission to arbitration always needs an agreement of the parties - the AIFC Court may have jurisdiction without a choice of court agreement - and the parties to arbitration are the ones who appoint the arbitrators even if, under the NYCV, the term 'arbitral awards' includes 'those made by permanent arbitral bodies'. ${ }^{103}$

Even if Kazakhstan itself has denied the AIFC Courts their status as domestic courts, courts of third countries may take the view that the AIFC Courts are, after all, a judiciary body of a sovereign nation, with the same attributes as any other judiciary body, so that its rulings may be afforded the status of foreign judgments, for the purposes of recognition. A sovereign state may divide its territory internally any way it deems fit and may set up specialised adjudicatory bodies if it so wishes, while at the same time remaining a single political and legal unity, vis à vis the outside world.

Furthermore, '[i]f an international treaty ratified by the Republic of Kazakhstan provides rules different to those provided by the [AIFC] Constitutional Statute, the rules of the international treaty must be applied' ${ }^{104}$ This provision seems to guarantee the recognition and enforcement of foreign judgments and foreign arbitral awards within the AIFC, in accordance with the treaties ratified by Kazakhstan, but not vice versa, that is, the AIFC Court will have to act as a municipal court of Kazakhstan for the purposes of enforcing foreign court rulings inside the AIFC, but the recognition of AIFC

101. Rule 30.11 AIFC Court Rules.

102. E.g. Minsk Convention of 1993, Kiev Agreement of 1992, Kishiniev Convention of 2002 and some bilateral treaties with UAE, India, etc.

103. Art. 1.2 NYCV.

104. Art. 4.4, AIFC Constitutional Statute.
Court decisions outside Kazakhstan may not benefit from those same treaties.

Finally, regardless of the nature and status of decisions made by the AIFC Court or by the arbitration panels of the IAC, the AIFC is clearly within and part of the territory of the Republic of Kazakhstan and under its full sovereignty, so if a judgment debtor has assets anywhere within that territory - including the AIFC - a foreign judgment creditor should be able to avail itself of the benefits of a valid and applicable treaty on recognition or of any future unilateral rules on recognition that are introduced in the legal system of the AIFC. As with any other country, Kazakhstan is bound by its international obligations with respect to its entire territory, 'unless a different intention appears from [a] treaty'. 105

Furthermore, the domestic courts and other state bodies of Kazakhstan retain some residual jurisdiction over individuals and legal entities established within the AIFC with respect, for instance, to administrative and criminal matters. ${ }^{106}$ This understanding of AIFC Courts as part of the judiciary of Kazakhstan may be reinforced by the fact that its budget derives from public state funds, as in the case of the other offshore courts. All this may indicate that the AIFC and the AIFC Court should not be seen as completely detached from the legal system of the host country.

The recognition and enforcement rules of the DIFC have been more tested in practice. The DIFC Courts, the courts of Dubai, other government bodies of the $\mathrm{UAE}$ and foreign judiciary bodies have signed several agreements, protocols, MoUs or memoranda of guidance (MoGs). ${ }^{107}$ Although recognition and enforcement on the basis of MoGs seem to be effective, their legal nature remains an issue. ${ }^{108}$ For instance, the MoG between the Supreme Court of Kazakhstan and the DIFC Courts provides that 'it has no binding legal effect' and that '[i]t does not constitute a treaty or act'. 109

Enforcement of offshore judgments within the DIFC is also entrusted to a DIFC enforcement judge and is done entirely in accordance with the centre's internal laws and court rules. ${ }^{110}$

105. Art. 29 United Nations, 'Vienna Convention on the Law of Treaties', 23 May 1969, 1155 United Nations Treaty Series 331; Art. 4, International Law Commission, 'Draft Articles on Responsibility of States for Internationally Wrongful Acts', November 2001, Supplement No 10 (A/56/10), chp.IV.E.1; J. Abbot, 'Clifford Chance Client Briefing', March 2018, at 3, available at: https://www.cliffordchance.com/ briefings/2018/03/emergence_of_a_regionalfinancialcentreastan.html.

106. Supra, n. 35

107. Available at: https://www.difccourts.ae/courts-programmes/protocolsand-memorandums-of-understanding/.

108. For a thorough study of the nature and usefulness of MoGs, vid. Saito, Hikari, 'Paving the Way for Another Direction in Promotion of Enforcement of Foreign Judgments', (Masters' Thesis at Kobe University, submitted 30 January 2019).

109. 'Memorandum of Guidance as to Enforcement between Supreme Court of the Republic of Kazakhstan \& DIFC Courts', 28 August 2015, para. 2, available at: https://www.difccourts.ae/2015/08/28/memorandumof-guidance-as-to-enforcement-between-supreme-court-of-therepublic-of-kazakhstan-difc-courts/.

110. Art. 7.1 DIFC Judicial Authority Law; Part 45 DIFC Court Rules. 
For the purposes of enforcement of DIFC Court judgments in Dubai, the judgment or judicial order must be final and executable, translated into Arabic and certified by the DIFC Courts. The enforcing party must obtain an execution letter from the DIFC Courts, addressed to the Chief Justice of Dubai; he must then file an application for enforcement to an execution judge of the 'onshore' Dubai courts, together with the execution letter and the official translation. The execution judge of the Dubai courts will deal with any challenges to the enforcement, but he may not reconsider the merits of the claim. Enforcement will be carried out in accordance with the procedural law of Dubai, as if they were judgments or orders issued by the onshore courts of Dubai. ${ }^{11}$ Dubai onshore courts also enforce DIFC interim orders such as freezing orders but, so far, not search orders. ${ }^{112}$

Enforcement of DIFC judgments in other UAE emirates is governed by UAE procedural law, which provides that the competent execution judge of Dubai will refer the DIFC judgment or order to the execution judge of the territory of the UAE where enforcement is sought. This latter execution judge of another emirate is competent for any procedural objections raised and will transfer to the execution judge of Dubai any property received as a result of the execution sale. It is not fully clear whether, in practice, DIFC courts can submit DIFC judgments directly to the final UAE execution judge outside Dubai. ${ }^{113}$

Since DIFC Courts are part of the Dubai judicial system, their judgments and orders profit from those recognition treaties to which the UAE is a party. ${ }^{114}$ The DIFC Courts can also be used as a 'conduit jurisdiction', so that recognition of foreign judgments and arbitral awards can be made within the DIFC and under DIFC law, for the purpose of enforcing them later on in Dubai or the UAE, but outside the DIFC. ${ }^{115}$

A further mechanism for the enforcement of DIFC Court judgments is that parties who have either submitted to the jurisdiction of the DIFC Courts or whose dispute falls, for any other reason, under the jurisdiction of DIFC Courts can agree - before or after a DIFC judgment has been issued - 'that any dispute arising out of or in connection with the non-payment of any money judgment given by the DIFC Courts may, at the option of the judgment creditor, be referred to arbitration under the Arbitration Rules of the DIFC-LCIA Arbitration Center'. ${ }^{116}$ This allows the enforcing party in DIFC litigation to transform its DIFC judgment into a DIFC-LCIA arbitration award, so as to have it recog-

111. Art. 7.3 DIFC Judicial Authority Law.

112. DIFC Enforcement Guide 2018, para. 15.

113. Art. 221 UAE Federal Civil Procedures Law (UAE Federal Law No. 11 of 1992); DIFC Courts Enforcement Guide 2018, paras. 16 et seq.

114. The UAE has entered into a number of multilateral treaties such as the GCC Convention of 1996, the Riyadh Convention of 1983 and bilateral treaties with Tunisia, France, Egypt, China and Kazakhstan.

115. DIFC Courts Enforcement Guide 2018, paras. 61 et seq.

116. DIFC Courts Practice Direction No. 2 of 2015 on Referral of Judgment Payment Disputes to Arbitration; DIFC Courts Enforcement Guide 2018, paras. 67 et seq. nised and enforced under the more favourable NYCV, to which many more countries are a party.

Alustath is sceptical about this last possibility because (a) a confirmatory award would not fall under the definition of arbitration, for the purposes of the NYCV, since arbitrators would not be settling any real substantive dispute; (b) there cannot be an 'exequatur on an exequatur'; and (c) the confirmatory award would encroach on the foreign domestic courts which would otherwise have jurisdiction for the recognition and enforcement proceedings of the court judgment. ${ }^{117}$ Arbitration tribunals can typically convert any parties' settlement agreements into arbitration awards, which are recognisable and enforceable under the NYCV, but such possibility is provided in the applicable arbitration laws and arbitration rules themselves.

The ADGM and the Abu Dhabi Judicial Department have also signed an $\mathrm{MoG}$ for the reciprocal enforcement of judgments, so ADGM Courts may put an enforcement judge of the Abu Dhabi Judicial Department in charge of enforcing ADGM Court judgments outside the ADGM. Alternatively, a judgment creditor may apply directly to the Abu Dhabi Judicial Department (ADJD) for the enforcement of ADGM Court judgments within Abu Dhabi. ${ }^{118}$ With respect to judgments from other UAE emirates, recognition within the ADGM is granted only if a previous agreement or $\mathrm{MoG}$ has been signed. ${ }^{119}$

Concerning the recognition and enforcement of foreign judgments and foreign arbitral awards within the ADGM, the ADGM Courts will recognise and enforce such judgments and awards in accordance with treaties entered into by the UAE, as well as in accordance with its own internal procedural law. ${ }^{120}$ Where judgments originate from countries that are not a party to a relevant treaty, the Chief Justice of the ADGM, after consultation with the Chairman of the Board of the ADGM, and after being satisfied that substantial reciprocity of treatment will be accorded, will order that such foreign courts be treated as 'recognized foreign courts', so that their money judgments - excluding tax payments or penalties - can be enforced within the ADGM.

The foreign judgment or foreign order for interim payment must be final and conclusive "notwithstanding that an appeal may be pending against it, or that it may still be subject to appeal, in the courts of the country of the original court'. Registration of the foreign judgments at the ADGM Courts must be effected within six years of the date of the judgment.

The ADGM Court will not re-examine the merits of the case and can only refuse recognition on very limited grounds: if the foreign judgment has been wholly or partially satisfied (partial enforcement is also possible);

117. Alustath, above n. 38 , at $172-73$

118. Art. 13.11 ADGM Law and MoG between ADGM and ADJD, dated 11 February 2018, paras. 13 and 14.

119. MoG between the ADGM and the UAE Emirate of Ras Al Khaimah, dated 16 November 2017.

120. Rule 170 et seq, ADGM Court Regulations. 
if the judgment could not be enforced in the country of origin; if the original court had no jurisdiction; if the debtor was not duly served; if the judgment was obtained by fraud; if the rights under the judgment are not vested in the person by whom the application for registration was made; if the judgment is contrary to the public policy of the ADGM or of Abu Dhabi; or if the subject matter of the case has also been the object of a final judgment of another court having jurisdiction over the matter. ${ }^{121}$

For the purposes of denial of recognition on the grounds of lack of jurisdiction, the foreign court of origin will be deemed to have jurisdiction in the following cases: (a) in actions in personam, if the debtor voluntarily appeared in the proceedings or was the claimant or counter-claimant; if the debtor was a resident in or, if it is a legal entity, was registered under the laws of the forum; or if the debtor had an office or place of business in the forum and the proceedings dealt with a transaction effected through that office or place; (b) in actions in rem for immovable or movable property, jurisdiction is also deemed to have existed if the property was situated in the forum at the time of the proceedings; (c) in any other cases where the laws and regulations of the ADGM expressly recognise the jurisdiction of the rendering court. If there is an appeal pending against the foreign judgment, the ADGM Court has the discretion to set aside the registration for recognition or to stay the application for setting aside. ${ }^{122}$

The QFC internal regulations establish that judgments and orders of the QFC Courts are judgments or orders of the courts of Qatar and therefore 'capable of enforcement and execution by the courts of Qatar as would be a judgment or order of any other Qatari court'. ${ }^{123}$ The authorities of Qatar must provide as much cooperation to QFC Courts as it is necessary for enforcement. However, the QFC Court rules add that a QFC enforcement judge will be 'primarily responsible for the enforcement of the Court's judgments, decisions and orders'. Application for enforcement of QFC judgments must be made primarily to this enforcement judge, who can enforce it by the levy of fines, orders and also by referring the matter to the relevant competent agency or authority of Qatar, in which case a translation into Arabic is required.

There are no specific provisions concerning recognition of QFC judgments in other UAE emirates or abroad, or about the recognition of foreign judgments and judgments from other domestic courts of the UAE within the QFC. However, the reference to QFC judgments as domestic judgments of Qatar may imply that the former profit from all the advantages of being Qatari judgments and, vice versa, that QFC Courts must recognise foreign judgments on the same terms that Qatar courts do.

121. Rule 173 and 175, ADGM Court Regulations.

122. Rule 175 ADGM Court Regulations.

123. Art. 34, QFC Court Rules.

\section{Powers of the Courts and International Judicial Cooperation}

The courts of these financial centres can produce orders with respect to detention, custody, inspection, sale or preservation of relevant property, access to buildings, freezing orders and search orders, orders for the production of documents and preservation of evidence, appointment of a receiver or trustee or ordering a party to deliver its passport and interim payments, among other things. The list of possible interim remedies and orders of the AIFC Court Rules, as well as the procedure to grant them, mirrors the corresponding list of the DIFC Court Rules. ${ }^{124}$

The court rules of these centres also address the topic of international civil cooperation in different headings concerning applications for assistance from foreign requesting courts, including onshore courts of the host country but always for the purposes of civil proceedings that have already commenced or are about to commence. ${ }^{125}$ With an appropriate application supported by evidence, these courts can issue several types of orders concerning examination of witnesses, requiring witnesses to make a deposition, production of documents or inspection of property.

The ADGM Court rules also provide that witnesses can be compelled to attend the trial, even if such witnesses are not within the jurisdiction of the ADGM Court but in Abu Dhabi. For this purpose, the ADGM Court can appoint an examiner or commissioner to take the evidence 'outside the jurisdiction'. ${ }^{126}$ The ADGM Court rules also provide that 'any person appointed by a court or other judicial authority of any foreign state shall have the power to administer oaths in the ADGM for the purpose of taking evidence for use in civil proceedings'. ${ }^{127}$

\section{The Relationship between the 'Offshore' Courts and the Arbitration Centres}

Each of the four financial centres examined has established some sort of arbitration court or dispute resolution centre offering arbitration and/or mediation services as an alternative to its own offshore litigation system. ${ }^{128}$ Such institutions function independently and

124. See Part 25 DIFC Court Rules; Part 15 AIFC Court Rules.

125. Art. 74 et seq. ADGM Court Regulations and Rule 18.62 et seq. AIFC Court Rules.

126. Arts. 40 and 77 ADGM Court Regulations.

127. Art. 77 ADGM Courts Regulations.

128. Art. 8 DIFC Law; Art. 14 AIFC Constitutional Statute; Art. 48 et seq. AIFC Arbitration Regulations of 2017; Law 2 of 2017 Promulgating the Civil and Commercial Arbitration Law of the QICDRC. 
possess their own legal personality, their own budget and their own internal boards of trustees, chairperson and chief executive. ${ }^{129}$ As in the case of the courts, world-renowned experts from common law jurisdictions have been appointed to those management and supervisory bodies. In some cases, each centre has established its arbitration mechanism through some sort of partnership with another, more experienced arbitration institution: the LCIA - in the case of the DIFC - and the ICC - in the case of the ADGM. However, the ADGM Arbitration Centre provides only certain services for arbitration hearings and is not a full-fledged arbitration institution that manages and oversees arbitration proceedings.

These arbitration mechanisms are independent of any other arbitration institution that may already exist in the host country and their arbitration laws, and rules are also different. The arbitration laws of the AIFC, ADGM and QFC expressly indicate that the arbitration legislation of their host country does not apply within the respective financial centre. ${ }^{130}$

The laws of the four financial centres provide for the enforcement - within the centre or within the host country - of arbitral awards made within each centre, as if they were judgments of the offshore Courts. For this purpose, the DIFC and AIFC courts may enter judgment in the terms of the award. ${ }^{131}$ Conversely, within the AIFC and 'in accordance with' the domestic laws of Kazakhstan, ${ }^{132}$ the AIFC Courts must recognise and enforce the awards made under the rules of other arbitration institutions of Kazakhstan. ${ }^{133}$

Awards made by the arbitration tribunals of these centres can be set aside in accordance with their own laws or regulations. ${ }^{134}$ The only grounds for setting aside offshore arbitral awards are those of the UNCITRAL Model Law, but any references to domestic laws are references to the law of the centre, whereas references to a conflict with public policy are references to the public policy of the host country.

Concerning appeals against IAC arbitral awards, although the AIFC Court rules provide that AIFC awards will be enforced in Kazakhstan in the same way as AIFC Court judgments, the AIFC Constitutional Statute mentions that such awards are to be enforced in the same way, and on the same terms as, arbitration

129. Art. 8 DIFC Law (DIFC Arbitration Institute); Art. 14 AIFC Constitutional Statute and AIFC Arbitration Regulations (AIFC International Arbitration Center).

130. Art. 7 AIFC Arbitration Regulations of 2017; Art. 3.2 ADGM Arbitration Regulations of 2015; Art. 2 QFC Arbitration Regulations of 2005

131. Art. 27.49 AIFC Court Rules; Art. 43.75 DIFC Court Rules; Art. 34 Arbitration Law 2 of 2017 of QFC; Art. 180 ADGM Courts Regulations; Art. 56 ADGM Arbitration Regulations 2015; Art. 232 ADGM Court Procedure Rules of 2016.

132. Arts. 14.3 and 14.4, AIFC Constitutional Statute.

133. E.g. International Arbitration Court, available at: http://arbitration.kz/ main; Atameken Arbitration Center of the National Chamber of Entrepreneurs, available at: https://aca.kz/site?lang=ENG

134. Art. 41 DIFC Arbitration Law 1 of 2008 (amended in 2013) (DIFC Arbitration Law); Art. 44 AIFC Arbitration Regulations; Art. 33 Law 2 of 2017 Promulgating the Civil and Commercial Arbitration Law of the QICDRC. awards issued by arbitration institutions in the Republic of Kazakhstan'. ${ }^{135}$ This apparent contradiction may have concerned some local practitioners, who fear that the domestic courts of this country may operate as appeal courts with respect to arbitration awards, ${ }^{136}$ as it happened in the past. ${ }^{137}$

In accordance with their own procedural rules, the offshore courts may also enforce interim measures adopted by arbitration tribunals, as well as assist in the taking of evidence, for instance, by issuing witness summons. ${ }^{138}$

The offshore courts themselves, in accordance with each centre's internal norms and regulations, recognise foreign arbitral awards within each financial centre. The grounds for refusal of recognition usually mirror those of the NYCV. ${ }^{139}$ However, in the cases of the DIFC and the AIFC, if Dubai or Kazakhstan are parties to an applicable treaty on recognition, that treaty will take precedence over the arbitration laws of these two financial centres and over their internal rules on recognition. 140

\section{Independence and Management of the Courts. Appointment and Removal of Judges}

The success of any adjudicatory mechanism may depend on its funding and independence. A good way to test the independence of the courts under study may be to analyse the process of appointing, disciplining and removing judges (especially Chief Justices, given their key role in the management of the courts), court registrars and heads of arbitration centres. It is also important to analyse their financial independence and the process whereby the budget and annual financial statements are prepared and submitted to the authorities of the host country. ${ }^{141}$ The laws and regulations of these courts also provide for some sort of immunity from liability for their judges. ${ }^{142}$ Another way that independence and due

135. Art. 14.3 AIFC Constitutional Statute.

136. Meeting of IAC officials with Almaty law firms and arbitration institutions, KIMEP University, 7 June 2018, Almaty.

137. A. Korobeinikov, Baker McKenzie, 2017 Arbitration Yearbook Kazakstan (2017) at 265, available at: https://globalarbitrationnews.com/wpcontent/uploads/2017/06/Kazakhstan.pdf.

138. Art. 43.48 et seq. DIFC Court rules; Arts. 27.30 et seq. AIFC Court Rules; Arts. 27 and 28. ADGM Arbitration Regulations of 2015; and Art. 17 Law 2 of 2017 on Arbitration of the QFC.

139. The UAE (for Dubai and Abu Dhabi) ratified the NYCV in 2006, and Qatar did in 2002. Kazakhstan has been a party to the NYCV since 1995, but some scholars have misgivings about its applicability by the domestic courts of the country (L. Tieulina, Legal Insight Magazine, 6(42) August 2015)

140. Art. 45 AIFC Arbitration Regulations and Art. 42.1 DIFC Arbitration Law.

141. Art. 8 DIFC Law; Art. 10 ADGM Court Regulations; Art. 13.2 AIFC Constitutional Statute; Art. 9 AIFC Court Regulations; Schedules 5 and 6 QFC Law.

142. E.g. Art. 22.8 ADGM Law. 
process is guaranteed is by ensuring the publicity of court proceedings. ${ }^{143}$

The Chief Justice of the AIFC Court and the remaining judges are appointed and removed by the President of the Republic of Kazakhstan on the recommendation of the Governor of the AIFC, who is also appointed and removed by the President himself. ${ }^{144}$ The appointment of AIFC judges, other than the Chief Justice, is made in consultation with the latter. Removal of AIFC judges is possible in case of ill health, bankruptcy, criminal offence or serious misconduct, as it is also the case of the QFC. The AIFC provisions may add a measure of independence in this process of removal because its Chief Justice can establish a procedure of investigation to determine allegations of misconduct. ${ }^{145}$

The DIFC's Chief Justice and other judges are directly appointed by the sovereign of Dubai, ${ }^{146}$ whereas in the case of the remaining courts the appointment process is done in consultation with other authorities, which may add a degree of independence. For instance, the Chief Justice of the ADGM Courts is appointed by the Board of Directors of this centre, ${ }^{147}$ which is made up of no less than five members appointed by the Executive Council of Abu Dhabi, an advisory body to the Ruler of the Emirate, made up of members of different government departments and other local authorities. The remaining judges of the ADGM Courts are appointed by the ADGM Board but based on proposals made by the Chief Justice. The Chairmen and judges of the QFC Regulatory Tribunal and of its Civil and Commercial Court are appointed by the Council of Ministers of Qatar. They are removed by this same body in case of ill health, bankruptcy, criminal offence or serious misconduct. ${ }^{148}$

The AIFC has its own budget, but there is also a reference to the transfer of funds to the AIFC Courts in accordance with the budget legislation of the Republic of Kazakhstan'. ${ }^{149}$ The Dispute Resolution Authority of the DIFC also has an independent budget that includes the Courts' budget. ${ }^{150}$ Such budgetary independence is also the case for the ADGM. ${ }^{151}$ The QFC Courts also have an independent budget, but, in this case, the budget laws of the Emirate are not applicable. ${ }^{152}$

The Chief Justices of these offshore courts are commonly in charge of preparing the budget of the court, as well as the annual financial accounts. Final approval of the courts' budget lies solely with a governmental body - in the case of the DIFC, ADGM and QFC - or with the centre's authorities - in the case of the AIFC. Remuner-

143. Rule 98 ADGM Court Regulations; Rule 23.79 DIFC Court Rules; Part 22 AIFC Court Rules; Art. 32 AIFC Court Regulation. All these provisions call for proceedings to be held in public.

144. Art. 10 and Art. 13.3 AIFC Constitutional Statute.

145. Art. 14 AIFC Court regulations.

146. Art. 8 DIFC Law.

147. Arts. 6 and 13 ADGM Law.

148. Schedules 5 and 6 QFC Law 7.

149. Art. 19 AIFC Court Regulations.

150. Art. 8 DIFC Law.

151. Art. 10 ADGM Law

152. Art. 8.5 QFC Law. ation of judges is typically entrusted to the same authorities or bodies that are competent for their appointment and removal. In the case of the AIFC, such remuneration cannot be reduced while the judges are in office. ${ }^{153}$ In countries with significant currency rate fluctuations - such as Kazakhstan - paying foreign judges in a hard currency, rather than in the local tenge, is an additional working benefit. However, as in the case of Kazakhstan, the domestic employment legislation may generally prohibit this, without specific legislation.

Chief Justices have other important functions, such as the appointment of registrars, execution judges and other officials and personnel of the courts, their day-to-day management and supervision, creating, or recommending the creation of, special court divisions and, in some cases, approving or providing advice in the making of court rules and other internal norms.

The number of judges employed may also be an important guarantee of efficiency. Nevertheless, sometimes there are only vague references to an amount that is 'sufficient to deal expeditiously with the cases pending before the Court', in the case of the AIFC. ${ }^{154}$ There are also flexible requirements concerning the term for which judges are appointed, as well as for their renewal, the good character conditions necessary for appointment, English language skills, age limits and their knowledge and experience or qualifications in the law of a common law jurisdiction. Judges are also typically allowed to hold office in other jurisdictions at the same time that they are members of the courts of these financial centres. ${ }^{155}$

\section{Conclusions}

OFCs that also offer dispute resolution services have become increasingly common in jurisdictions eager to attract foreign investors and whose legal and judiciary systems are either defective or not attractive enough for those same future investors and for their legal advisors. However, it is fair to ask whether the effort of implementing such mechanisms would not be better invested in ordinary legal and judicial reforms for the whole country and whether these initiatives fit well into their complicated constitutional law systems, which still have some way to go in terms of their democratic deficit, separation of powers and respect for the rule of law. Where lawyers and businessmen usually trust the domestic court system, it may be more practical to just open English-speaking sections of ordinary commercial courts, with broad rights of audience for foreign lawyers, as is done in some European and South-East Asian jurisdictions.

AIFC law really tries to insulate its activities and its Participants from the rest of the country, but it may not

\footnotetext{
153. Art. 16 AIFC Court Regulations.

154. Art. 10 AIFC Court Regulations.

155. Arts. 11 and 12, AIFC Court Regulations; Art. 9 DIFC Court Law; Art. 192 ADGM Court Regulations; Schedule 6, para. 2 QFC Law.
} 
attract enough trust if there is uncertainty concerning its interpretation or concerning the relationship with onshore domestic courts. Contrary to the DIFC, where the UAE Federal Supreme Court and the Dubai Supreme Court have a coordinating role, the AIFC Court is expressly excluded from the domestic judicial system of Kazakhstan, so it remains to be seen if the Supreme Court of this country will properly assume that coordinating role on the basis of the constitutional law nature of the AIFC's founding legislation. ${ }^{156}$ In this regard, one of the tasks assumed by the International Council of the Supreme Court of the Republic of Kazakhstan is to interact with the AIFC Court. ${ }^{157}$ The AIFC Court is also very actively reaching out to the legal and academic world of the country. ${ }^{158}$

This degree of uncertainty may worry those Kazakhstani law firms that now have to advise their clients on the inclusion of choice of court and arbitration clauses providing for the jurisdiction of the AIFC Court and IAC, in any contracts presently being drafted and negotiated. ${ }^{159}$

Nevertheless, these offshore courts may yet prove to be a powerful tool that will in time drag the entire legal and judicial system of the country behind if there are good relations between the offshore and the onshore institutions. If such relations are harmonious and local courts do not see these new courts as 'uninvited guests', there could be very good reciprocal influences. If, on the other hand, local courts show themselves too jealous of their own jurisdiction, there could be complications.

The criticism that is sometimes made of international commercial and investment arbitration for being opaque and unaccountable may be unfair here because the rules of these new offshore courts seem to guarantee publicity and are under the guardianship of sovereign nations. However, it remains to be seen whether another common criticism - the elitism of international arbitration, to which only sophisticated parties have access - can also be made of these courts. That most disputes at the DIFC are employment related may point in the opposite direction. ${ }^{160}$

Courts staffed by English judges who apply English law sound like a good idea for the business community at

156. Art. 4.1 AIFC Constitutional Statute.

157. Art. 5.3 Regulation of the International Council of the Supreme Court of the Republic of Kazakhstan, as confirmed by the decision of the plenary session of the Supreme Court, 15 February 2016, available at: http://sud.gov.kz/rus/content/polozhenie-mezhdunarodnogo-sovetapri-verhovnom-sude-respubliki-kazahstan

158. Available at: http://aifc-court.kz/press-releases.

159. In a lecture given at KIMEP University (Almaty) on 19 April 2019, by Sir Jack Beatson, Justice of the AIFC Court, and by Mr Christopher Campbell-Holt, Registrar and Chief Executive of the AIFC Court, it was informed that, so far, choice of forum clauses choosing the AIFC Court have been inserted in 250 contracts. In addition, they were confident that, not only for legal reasons, but also owing to the good relationship that the AIFC enjoys with the Government and with the Supreme Court, the local judiciary will in no case attempt to review any AIFC rulings or arbitral awards.

160. Around $60 \%$ in 2017, available at: https://www.thenational.ae/ business/difc-courts-cases-up-41-in-2017-led-by-small-claimstribunal-1.706095. large, especially in Persian Gulf countries, which have had a long relationship with the UK. Given the cosmopolitan population of the UAE and Qatar, it may have come as a relief for 'expats' to have English-speaking courts at their disposal, although it may also strengthen the Anglo-Saxon cultural grip on the world.

However, the foreign, English-speaking population of Kazakhstan is much smaller, and it remains to be seen how many foreign companies are lured by the calls of the charismatic President Nazarbayev, who continues to be an influential figure, despite his resignation last March. Some fear that this will be just another bluff, like the failed Almaty Financial District, where a bunch of people will again profit from the public funding devoted to this new ambitious project. ${ }^{161}$ The procedural advantages of English-style litigation - such as discovery and the precedent system - may add to the attractiveness of these mechanisms but may be seen as discriminatory for potential litigants from the rest of the host country, who may not be able to afford to establish themselves within this new financial centre or voluntarily submit to its jurisdiction.

Offshore courts of OFCs are in practice 'jurisdictions of refuge' and, for many practical purposes, 'jurisdictions within jurisdictions'. They may provide another example of the flight from state justice, akin to arbitration, to be studied by the theories of delocalisation. Offshore courts and international business courts may show how the postmodern state is increasingly abandoning the rationalistic, egalitarian Napoleonic tenets of nineteenth-century justice and inadvertently moving back to the more interesting but more chaotic distribution of powers of Medieval Europe.
161. Available at: https://www.fdiintelligence.com/Locations/Asia-Pacific/ Kazakhstan/Is-Kazakhstan-s-new-financial-center-for-real. 